\title{
Factors associated with choosing Nephrology as a subspecialty by Internal Medicine Residents in Nigeria
}

\author{
*Oyebisi. O.O. ${ }^{1}$, Adeyera. O. ${ }^{2}$, Alebiosu C.O. ${ }^{3}$
}

\begin{abstract}
Background: There is a projected shortage of kidney specialists in Nigeria and there is need to train more residents in nephrology to meet the need of the teaming population of patients with chronic kidney Disease. The study identify factors affecting the choice of Nephrology among resident doctors in selected training institutions in Nigeria.
\end{abstract}

Methods: This cross-sectional study was conducted among the resident doctors in Internal Medicine in four randomly selected training institutions across the northern and southern parts of Nigeria. We developed a self-administered questionnaire in the English language after a thorough review of relevant literature. Data were gathered through the two-part questionnaire. In the first part, demography, gender, age, marital status, and level of training were documented and the second section included 24 questions about factors that influence the residents' choice of subspecialty.

Results: A total of 78 respondents were interviewed. The mean age of the respondent was $33.52 \pm 3.52$. A higher proportion of the respondents were males $(70.5 \%), 56.4 \%$ were senior registrars with the mean residency year of $3.46 \pm 2.00$. A total of $52.6 \%$ never had interested in nephrology as a career choice while of $47.4 \%$ that showed interest in nephrology, only $11.5 \%$ are currently in Nephrology. Most of those who had interest in Nephrology changed their mind along the line and are now registrars or senior registrars in other subspecialty. The most common factors identified were advice from other mentors or senior consultants $(80.8 \%)$, outcome of most patients with renal condition $(79.5 \%)$ and positive role model in nephrology medicine $(76.9 \%)$. The least identified factors were prestige and respect accorded a nephrologist (35.9\%) and societal expectation, peer encouragement and family's expectations (42.3\%).

Conclusion: There is an urgent need to address factors that affects the choice of Nephrology. Effective steps towards addressing these factors may go a long way in improving the internal medicine residents' choice of Nephrology as a career in the near future.

Key words: career decisions, education, nephrology, training, Nigeria

\author{
*Corresponding author \\ Oyebisi O.O. \\ http://orcid.org/0000-0003-3241-1587 \\ Email: oyebisi_oyekunle@yahoo.com \\ ${ }^{1}$ Olabisi Onabanjo University Teaching Hospital, Sagamu, Nigeria \\ ${ }^{2}$ Department of Community Medicine, College of Health Sciences, Osun State University, Osogbo, Nigeria \\ ${ }^{3}$ Yale University School of Medicine/ Department of Medicine, Jackson F. Doe Regional Referral Hospital / A.M. \\ Dogliotti College of Medicine, University of Liberia, Monrovia, Liberia.
}




\title{
Facteurs associés au Choix de la Néphrologie comme une sur Spécialité par les Résidents en Médecine Interne au Nigéria
}

\author{
Oyebisi. O.O. ${ }^{1}$, Adeyera. O. ${ }^{2},{ }^{*}$ Alebiosu C.O. ${ }^{3}$
}

\begin{abstract}
Résumé
Contexte général de l'étude: On prévoit un manque de spécialistes de la fonction rénale au Nigéria et il est nécessaire de former davantage de résidents en néphrologie pour répondre aux besoins de la population de patients atteints d'une maladie rénale chronique qui fait équipe. L'étude identifie les facteurs qui influent sur le choix de la néphrologie parmi les médecins résidents dans certains établissements de formation au Nigéria.
\end{abstract}

Méthodes de l'étude: Cette étude transversale a été menée parmi les médecins résidents en médecine interne de quatre établissements de formation choisis au hasard dans le nord et le sud du Nigéria. Nous avons développé un questionnaire auto-administré en anglais après un examen approfondi de la littérature pertinente et valable. Les données ont été recueillies au moyen du questionnaire en deux parties. Dans la première partie, la démographie, le sexe, l'âge, l'état matrimonial et le niveau de formation ont été documentés et la deuxième section comprenait 24 questions sur les facteurs qui influencent sur le choix de la sur spécialité par les résidents.

Résultats: Au total, 78 répondants ont été interviewés. L'âge moyen du répondant était de $33.52 \pm 3.52$. Une proportion plus élevée de répondants étaient des hommes (70.5\%), 56.4\% étaient des officiers d'un grade supérieur avec une année de résidence moyenne de $3.46 \pm 2.00$. Au total, $52.6 \%$ ne se sont jamais intéressés à la néphrologie comme choix de carrière, alors que $47.4 \%$ de ceux qui ont manifesté de l'intérêt pour la néphrologie, $11.5 \%$ seulement sont actuellement en néphrologie. La plupart de ceux qui s'intéressaient à la néphrologie ont changé d'idée par conséquence, sont maintenant des officiers d'un grade supérieur d'une autre sous-spécialité. Les facteurs les plus fréquemment identifiés étaient les conseils d'autres mentors ou de consultants supérieurs $(80.8 \%)$, de la plupart des patients présentant une maladie rénale $(79.5 \%)$ et un modèle positif en médecine de la néphrologie $(76.9 \%)$. Les facteurs les moins identifiés étaient le prestige et le respect d'un néphrologue (35.9\%) et les attentes de la société, les encouragements des pairs et les attentes de la famille (42.3\%).

Conclusion: Il est urgent de prendre en compte les facteurs qui influent sur le choix de la néphrologie. Des mesures efficaces pour faire face à ces facteurs pourraient grandement contribuer à améliorer le choix de la néphrologie en tant que carrière par les résidents en médecine interne dans un proche avenir.

Mots-clés: choix de carrière, éducation, néphrologie, formation, Nigéria

\author{
*Auteur correspondant \\ Alebiosu C.O. \\ http://orcid.org/0000-0001-6224-6039 \\ Email: christopher.alebiosu@yale.edu
}

${ }^{1}$ Olabisi Onabanjo University Teaching Hospital, Sagamu, Nigeria

${ }^{2}$ Department of Community Medicine, College of Health Sciences, Osun State University, Osogbo, Nigeria

${ }^{3}$ Yale University School of Medicine/ Department of Medicine, Jackson F. Doe Regional Referral Hospital / A.M. Dogliotti College of Medicine, University of Liberia, Monrovia, Liberia. 


\section{INTRODUCTION}

Chronic kidney disease (CKD) has become a public health problem due to its increasing prevalence globally and associated high morbidity and mortality (1-3). The burden of CKD is more felt in developing countries like Nigeria where there is no health insurance to meet the huge financial demands the disease places on its sufferers and their families (4).

Despite the teeming population of patients with $\mathrm{CKD}$, there is inadequate number of Nephrologists in Nigeria to cater of them. One of the most important components of developing nephrology services in many areas of the country is the training of nephrologists who will prioritise renal disease and seek out patients who need care, but the ratio of nephrologists per population in Nigeria is still one of the lowest in the world, making comprehensive delivery of renal care extremely challenging. Presently, there are about 400 nephrologists in Nigeria (against the expected number of 1000 nephrologists) per one million population and the available ones are domicile within the urban centres making the rural areas to suffer (5).

There are many challenges bedevilling the nephrology subspecialty training program in Nigerian including poor funding, lack of basic infrastructure, inadequate health personnel, migration of few trained personnel as well as declining interest in choosing nephrology as a career. The already inadequate health systems of sub-Saharan Africa have been badly damaged by the emigration of the health professionals. Migration is seriously affecting the sustainability of health systems in many developing countries.

A 1998 UN Conference on Trade and Development/WHO study estimated that $56 \%$ of all migrating doctors flow from developing to developed nations, while only $11 \%$ migrate in the opposite direction; the imbalance is even greater for nurses (6). Medical students and young doctors in training need motivated, well educated, articulate champions of both the health service and their speciality. Loss of well-trained, experienced personnel is perhaps the most serious aspect for the future in many countries (6). Many migrant health professionals probably intend to return to practice in their own countries the problem for most countries, particularly in sub-Saharan Africa, is that many do not. In recent years, international migration of health professionals has not only grown considerably but is often permanent. Although many of these countries have made considerable efforts to train their own doctors, the rate of loss by migration often outstrips production.

Interest in nephrology career among internal medicine residents within the country is declining (unpublished personal observations) similar to developments in western countries (7). In the latter, however, concerted efforts have focused on identifying factors discouraging residents from choosing nephrology, in order to reverse the trend and increase interest in nephrology careers (8-10). Few studies have examined attitudes of internal medicine residents toward nephrology careers locally. In the US, there are several proposed reasons for this declining interest. These include difficult-tounderstand or unstimulating renal pathophysiology courses in medical school; disheartening inpatient experiences; few opportunities to experience the other aspects of nephrology careers like outpatient nephrology clinics, outpatient dialysis, kidney transplantation, and interventional nephrology; and perceived workload of nephrologists (11-13).

It is possible that there are common variables that play a role, including intellectual interest in the field, the presence or lack of a significant procedural component, earning potential, and ease of finding job opportunities. Furthermore, the experiences that students and trainees have are also likely to influence them as well, either positively or negatively.

\section{MATERIALS AND METHODS}

This cross-sectional study was conducted among the resident doctors in Internal Medicine in 4 randomly selected training institutions across the northern and southern part of Nigeria. The sample size of the study consists of all residents in Internal Medicine (junior and senior) who consented to participate in the study in the selected institutions.

We developed a self-administered questionnaire in the English language after a thorough review of relevant literature. Data were gathered through the two-part questionnaire. In the first part, demography, gender, age, marital status, and level of training were documented and the second section included 24 questions about factors that influence the residents' choice of subspecialty.

Questions were composed based on a Likert scale with five answers (very important, somewhat important, neutral, not very important, not at all important). The participants were asked to answer the questions on a Likert scale from 1 (very important) to 5 (not at all important) The Human Research and Ethics Committee of 
Osun State University approved the study protocol.

The data generated were recorded into SPSS software, then analysed and presented using the appropriate statistical format. Descriptive data were given as mean and standard deviation. Differences in distribution were analyzed by ANOVA and t-tests. The level of significance was taken as $\mathrm{p}<0.05$.

\section{RESULTS}

\section{Socio-demographic Characteristics}

A total of 78 respondents were interviewed in this study. The mean age of the respondent was $33.52 \pm 3.52$. A higher proportion of the respondents were males $(70.5 \%), 56.4 \%$ were senior registrars with the mean residency year of $3.46 \pm 2.00$. Almost one-third of the hospitals where respondents were selected in an urban area $(65.4 \%), 28.2 \%$ were in semi-urban and $6.4 \%$ were in rural areas. Most of the respondents were married $(74.4 \%), 23.1 \%$ were single and $2.6 \%$ were divorced.

\section{Choice of nephrology as a career choice among resident doctors}

Table 1 shows the interest in nephrology as a career choice among the respondents. A total of $52.6 \%$ never had interested in nephrology as a career choice while of $47.4 \%$ that had an interest in nephrology only $11.5 \%$ are currently in Nephrology. Most of those who had interest in Nephrology changed their mind along the line and are now registrars or senior registrars in other subspecialty.

Table 2 shows the perceived factors affecting nephrology as a career choice among residents. The most common factors identified were advice from other mentors or old consultants $(80.8 \%)$, outcome of most patients with renal condition $(79.5 \%)$ and positive role model in nephrology medicine $(76.9 \%)$. The least identified factors were prestige and respect accorded a nephrologist $(35.9 \%)$ and societal expectation, peer encouragement and family's expectations $(42.3 \%)$.

\section{Shortcomings of Nephrology as a subspecialty}

The most common shortcomings raised by the respondents were: inadequate and lack of standard diagnostic equipment, unavailable surgical interventions, expensive treatment which is unaffordable by the patients, high risk of death among patients and high demand for time.

Lack of scholarship opportunities for specialists, improper training and supervision, lack of social support for renal opportunity, late presentation of patients, high patient workload with few doctors, harsh working environment for women and hectic nature of the posting were the other shortcomings of nephrology raised by the respondents.

\section{Recommendations for increasing interest in nephrology}

Provision of standard equipment and working tools, improvement in the quality of services, provision of health insurance for patients with renal care, building governmental interest, financial support and subsidized fees for renal patients and mentorship to resident doctors were the major recommendations for increasing interest in Nephrology.

Allocation of more training postings in the subspecialty in order to increase manpower, better training ambience, creating a workfriendly environment, improving medical education in nephrology for undergraduates and postgraduates and provision of incentives to doctors were the other recommendations.

\section{DISCUSSION}

There is a general decline interest in Nephrology initially documented in developed world (14). By inference the situation in developing countries like Nigeria is worse due to increase in number of patients that need renal care in the face of dwindling number of Nephrologists as well as mass exodus of doctors from Nigeria to other developed countries in search of better opportunities. In this multi-center study, we looked at the choice of Nephrology as a subspecialty of Internal Medicine and some of the factors that could stimulate the interest or discourage interns from specializing in Nephrology. This became necessary because of the growing population of patients with kidney diseases both acute and chronic in Nigeria, without a corresponding increase in the number of Nephrologists that will provide adequate and effective care.

Majority of the residents were not interested in nephrology as a career. The most common factors identified were advice from other mentors or senior consultants $(80.8 \%)$, poor outcome of most patients with renal condition $(79.5 \%)$ and lack of positive role model in nephrology medicine $(76.9 \%)$. The least identified factors were prestige and respect accorded a nephrologist (35.9\%) and societal expectation, peer encouragement and family's expectations (42.3\%). This has demonstrated the 
importance of role model and patient outcome as the most important factors that affected the career choice in Nephrology among the studied population. Studies in other fields have suggested that the presence of fellows in a particular field can positively influences the resident choice of that subspecialty. In a survey, 178 internal medicine residents from three academic medical centers about their interest in pulmonary and critical care medicine (PCCM) subspecialty training, some of the factors associated with higher resident interest in PCCM training, include observing a high sense of satisfaction among PCCM fellows and receipt of encouragement from PCCM fellows about joining the field (15). The data from Canadian residents suggests that lack of exposure to fellows may negatively impact a resident's decision to apply to a specialty (16).

Among obstetrics and gynaecology residents, the presence of a gynaecologic oncology subspecialty training program at a primary teaching hospital was associated with a 4-fold higher resident career interest in that subspecialty (17).

Also the greater number of the participants who were interested in Nephrology as junior residents eventually found themselves as senior registrars in other subspecialties (18). The change in the choice of career may be due to negatives factors raised by the residents. The most common shortcomings by the respondents were: inadequate and lack of standard diagnostic equipment, unavailable surgical interventions, expensive treatment which is unaffordable by the patients, high risk of death among patients and high demand for time.

Lack of scholarship opportunities for specialists, improper training and supervision, lack of social support for renal opportunity, late presentation of patients, high patient workload with few doctors, women-harsh environment and hectic nature of the posting were the other shortcomings of nephrology raised by the respondents.

This study provided an insight into some of the reasons why internal medicine residents are gradually losing interest in choosing nephrology. Exposure to a field as a trainee may increase interest in that field; for example, in the Lorin study, residents who had spent more time in the intensive care unit were more likely to be interested in pulmonary/critical care (PCC) fellowship (15). Rotations during residency and medical school were cited as one of the most important experiences having a high impact on their career decision. Working with internal medicine residency programs to increase resident exposure to nephrology may increase interest in nephrology careers.

Some students and residents may be dissuaded from nephrology due to the complexity and intellectual challenge of the field. In our study, $61.5 \%$ of residents agreed that personal intelligence and ability is required to understand complex renal pathophysiology. This is corroborated by a study from Jordan in which individual competence was a major factor in choosing a specialty (19).

In a study, internal medicine nonnephrology subspecialty fellows cited the complexity of renal pathophysiology and lack of procedures as reasons for not choosing nephrology (20). In another study, $78 \%$ of medical students felt that renal pathophysiology was too complex, irrelevant, or not interesting (21).

The focus of Nephrology educators should be towards effective teaching strategies to improve student and resident confidence and sense of mastery (22-23).

Some of the suggestion provided by the respondents in this study include provision of standard equipment and working tools, improvement in quality of services, provision of health insurance for patients with renal care, building governmental interest, financial support and subsidized fees for renal patients and mentorship to resident doctors were the major recommendations for increasing interest in Nephrology. In addition, allocation of more training postings in the subspecialty in order to increase manpower, better training ambience, creating a work-friendly environment, improving medical education in nephrology for undergraduates and postgraduates and provision of incentives to doctors were the other recommendations. Effective steps towards addressing the above factors may go a long way in improving the internal medicine residents' choice of Nephrology as a career in the near future.

Conflicting Interests: The authors declare that there is no conflict of interest.

Acknowledgements: The authors will like to appreciate the Resident Doctors that participated in this survey.

\section{REFERENCES}

1. Alebiosu CO, Ayodele OE. The global burden of 
chronic kidney disease and the way forward. Ethn Dis. 2005; 15:418-23.

2. Levey AS, Atkins R, Coresh J, Cohen EP, Collins AJ, Eckardt KU, et al. Chronic kidney disease as a global public health problem: Approaches and initiatives - A position statement from Kidney Disease Improving Global Outcomes. Kidney Int. 2007;72:247-59.

3. Ulasi II, Ijoma CK. The enormity of chronic kidney disease in Nigeria: The situation in a teaching hospital in South-East Nigeria. J Trop Med. 2010;2010:501957.

4. Ijoma CK, Ulasi II, Kalu AO. Cost implications of treatment of end-stage renal disease in Nigeria. $\mathrm{J}$ Coll Med. 1998;3:95-6.

5. Nephrology Association of Nigeria. 30th annual scientific conference and general meeting, Ilorin, $\mathrm{t} h \mathrm{e} \quad \mathrm{K} w \mathrm{a} \mathrm{ra}, \quad 2018$. https://www.dailytrust.com.ng/3-in-10Nigerian-adults-have-kidney-disease-saysnephrologists.html Assessed Feb 13, 2018, 4:55 PM

6. Daniels MN, Maynard S, Porter I, Kincaid H, Jain D, Aslam N (2017). Career interest and perceptions of Nephrology: A repeated crosssectional survey of internal medicine residents. P L o S ONE 12(2): e 0172167. doi:10.1371/journal. pone.0172167.

7. National Resident Matching Program Specialties Matching Services Historical Reports, www.nrmp.org/ match-data/nrmp-historicalreports/, accessed 7/1/2016.

8. Parker MG, Ibrahim T, Shaffer R, Rosner MH, Molitoris BA. The future nephrology workforce: will there be one? Clin J Am Soc Nephrol. 2011; 6:1501-1506.

9. Parker MG, Pivert KA, Ibrahim T, Molitoris BA. Recruiting the next generation of nephrologists. Adv Chronic Kidney Dis. 2013; 20:326-335.

10. Adams ND. Attracting more residents into nephrology. Clin J Am Soc Nephrol. 2012; 7:1382-1384.

11. Parker MG, Ibrahim T, Shaffer R, Rosner MH, Molitoris BA: the future nephrology workforce: Will there be one? Clin J Am Soc Nephrol 6: 1501-1506, 2011

12. Rosner M, Parker M, Kohan D: Nephrology as a career choice: A survey of medical students [Abstract]. J AmSocNephrol 20: 767A: SAPO2867, 2009

13. Kohan DE: Training the next generation of nephrologists. Clin J Am Soc Nephrol 6: 2564-2566, 2011.

14. Estimating workforce and training requirements for nephrologists through the year 2010. Ad Hoc Committee on Nephrology Manpower Needs. $J$ Am Soc Nephrol 8[Suppl 9]: S9-13, i-xxii, 1-32

15. Lorin S, Heffner J, Carson S. Attitudes and perceptions of IM residents regarding pulmonary and critical care subspecialty training. Chest. 2005; 127:630-6.

16. Horn L, Tzanetos K, Thorpe K, Straus SE. Factors associated with the subspecialty choices of IM residents in Canada. BMC Med Educ. 2008; 8:37

17. Cohn DE, Roney JD, O'Malley DM, Valmadre S. Residents' perspectives on surgical training and the resident-fellow relationship: comparing residency programs with and without gynaecological oncology fellowships. Int $\mathrm{J}$ Gynecol Cancer. 2008; 18:199-204.

18. Sierles FS, Taylor MA. Decline of United States medical student career choice of psychiatry and what to do about it. Am J Psychiatry. 1995;152:1416-26.

19. Jhaveri KD, Sparks MA, Shah HH, et al. Why not nephrology? A survey of US IM subspecialty fellows. Am J of Kidney Dis. 2013; 61:540-6.

20. Parker MG, Ibrahim T, Shaffer R, Rosner MH, Molitoris BA. The future nephrology workforce: will there be one? Clin J Am Soc Nephrol. 2011; 6:15y01-1506.

21. Yousef K, Dema A, Zouhair A, Ahmad A, Mohammad K, Samar B, Khalid El S, Mousa O Factors affecting medical students in formulating their speciality preferences in Jordan. BMC Med. Edu. 2008; 8:32.

22. Hoenig MP Share your passion for nephrology: ten tips to invigorate attending rounds and precepting sessions. Amer J Kidney Dis. 2015; 66:28-32

23. Jhaveri KD, Sparks MA, Shah HH. Novel educational approaches to enhance learning and interest in nephrology. Adv Chronic Kidney Dis. 2013; 20:336-346. 
Table 1: Interest in Nephrology as a career choice

\begin{tabular}{ll}
\hline Variable & $\mathbf{n ( \% )}$ \\
\hline Neither chose nor interested & $18(23.1)$ \\
interested and already a Registrar in nephrology medicine & $8(10.3)$ \\
interested but already a Registrar in other internal & $9(11.5)$ \\
medicine specialities & \\
$\begin{array}{l}\text { Undecided but interested nephrology medicine } \\
\text { Not interested but already an SR in other internal } \\
\text { medicine Specialties }\end{array}$ & $20(25.6)$ \\
\hline
\end{tabular}

Table 2: Perceived factors affecting nephrology as a career choice

\begin{tabular}{|c|c|c|c|}
\hline & $\begin{array}{l}\text { Important } \\
\text { n (\%) }\end{array}$ & $\begin{array}{l}\text { Not } \\
\text { important } \\
\text { n (\%) }\end{array}$ & $\begin{array}{l}\text { Neutral } \\
\text { n (\%) }\end{array}$ \\
\hline \multicolumn{4}{|l|}{ Personal factors } \\
\hline Variable & $48(61.5)$ & $10(12.8)$ & $20(25.6)$ \\
\hline $\begin{array}{l}\text { Societal expectation, peer encouragement and family's } \\
\text { expectations }\end{array}$ & $33(42.3)$ & $21(26.9)$ & $24(30.8)$ \\
\hline $\begin{array}{l}\text { Length and difficulty of the training period of } \\
\text { Nephrologist }\end{array}$ & $45(57.7)$ & $16(20.5)$ & $17(21.8)$ \\
\hline \multicolumn{4}{|l|}{ Work environment } \\
\hline Future opportunity for promotion & $45(57.7)$ & $15(19.2)$ & $18(23.1)$ \\
\hline $\begin{array}{l}\text { Opportunities for performing a procedure (e.g. renal } \\
\text { biopsy, dialysis, tissue typing) }\end{array}$ & $56(71.8)$ & $12(15.4)$ & $10(12.8)$ \\
\hline Work-related hazards (infectious hepatitis, AIDS) & $45(57.7)$ & $19(24.4)$ & $14(17.9)$ \\
\hline Workload & $59(75.6)$ & $9(11.5)$ & $10(12.8)$ \\
\hline Prestige and respect accorded a Nephrologist & $28(35.9)$ & $20(25.6)$ & $30(38.5)$ \\
\hline Residency training with allowance for maternity leave & $39(50.0)$ & $17(21.8)$ & $22(28.2)$ \\
\hline Outcome of most patients with renal condition & $62(79.5)$ & $5(6.4)$ & $11(14.1)$ \\
\hline \multicolumn{4}{|l|}{ Finance and Training opportunity } \\
\hline Academic job opportunity in the university & $38(48.7)$ & $14(17.9)$ & $26(33.3)$ \\
\hline $\begin{array}{l}\text { Future opportunities like scholarships and frequent } \\
\text { international travels }\end{array}$ & $47(60.3)$ & $11(14.1)$ & $20(25.6)$ \\
\hline $\begin{array}{l}\text { Probabilities establishing a private practice after } \\
\text { completion }\end{array}$ & $53(67.9)$ & $13(16.7)$ & $12(15.4)$ \\
\hline $\begin{array}{l}\text { Annual income and Financial rewards of Nephrologist } \\
\text { relative to other specialists }\end{array}$ & $42(53.8)$ & $17(21.8)$ & $19(24.4)$ \\
\hline Free time for leisure of nephrologist & $49(62.8)$ & $15(19.2)$ & $14(17.9)$ \\
\hline Availability of full-time Nephrologist & $48(61.5)$ & $10(12.8)$ & $20(25.6)$ \\
\hline $\begin{array}{l}\text { Availability of postgraduate college approved } \\
\text { supervisor for nephrology medicine thesis in your } \\
\text { centre }\end{array}$ & $54(69.2)$ & $11(14.1)$ & $13(16.7)$ \\
\hline $\begin{array}{l}\text { Approval for external posting for Part II by the } \\
\text { hospital management }\end{array}$ & $46(59.0)$ & $14(17.9)$ & $18(23.1)$ \\
\hline \multicolumn{4}{|l|}{ Mentorship } \\
\hline Positive role model in nephrology medicine & $60(76.9)$ & $6(7.7)$ & $12(15.4)$ \\
\hline Advice from other mentors/old consultants & $63(80.8)$ & $9(11.5)$ & $6(7.7)$ \\
\hline $\begin{array}{l}\text { Experience during rotation in medical school and } \\
\text { residency }\end{array}$ & $57(73.1)$ & $7(9.0)$ & $14(17.9)$ \\
\hline
\end{tabular}

